\title{
Sex differences in migration and demography of a wide-ranging seabird, the northern gannet
}

\author{
Zoe Deakin $^{1,2}$, Keith C. Hamer ${ }^{3}$, Richard B. Sherley ${ }^{1,4}$, Stuart Bearhop ${ }^{2}$, \\ Thomas W. Bodey ${ }^{2}$, Bethany L. Clark ${ }^{1}$, W. James Grecian ${ }^{5}$, Matt Gummery ${ }^{6}$, \\ Jude Lane ${ }^{3}$, Greg Morgan ${ }^{7}$, Lisa Morgan ${ }^{7}$, Richard A. Phillips ${ }^{8}$, \\ Ewan D. Wakefield ${ }^{9}$, Stephen C. Votier ${ }^{1,2, *}$ \\ ${ }^{1}$ Environment and Sustainability Institute, University of Exeter, Penryn Campus, Cornwall TR10 9EZ, UK \\ ${ }^{2}$ Centre for Ecology and Conservation, University of Exeter, Penryn Campus, Cornwall TR10 9EZ, UK \\ ${ }^{3}$ School of Biology, University of Leeds, Leeds LS2 9JT, UK \\ ${ }^{4}$ Bristol Zoological Society, Clifton, Bristol BS8 3HA, UK \\ ${ }^{5}$ Scottish Oceans Institute, University of St Andrews, St Andrews KY16 8LB, UK \\ ${ }^{6}$ Marine Stewardship Council, Marine House, 1 Snow Hill, London EC1A 2DH, UK \\ ${ }^{7}$ RSPB Ramsey Island, St Davids, Pembrokeshire SA62 6PY, UK \\ ${ }^{8}$ British Antarctic Survey, Natural Environment Research Council, High Cross, Madingley Road, Cambridge CB3 0ET, UK \\ ${ }^{9}$ University of Glasgow, Institute of Biodiversity, Animal Health and Comparative Medicine, Graham Kerr Building, \\ Glasgow G12 8QQ, UK
}

\begin{abstract}
Marine vertebrates show a diversity of migration strategies, including sex differences. This may lead to differential demography, but the consequences of such between-sex variation are little understood. Here, we studied the migration of known-sex northern gannets Morus bassanus - a partial migrant with females $\sim 8 \%$ heavier than males. We used geolocators to determine wintering areas of 49 breeding adults (19 females and 30 males during 2010 to 2014) from 2 colonies in the northeast Atlantic (Bass Rock and Grassholm, UK). We also tested for sex-specific survival probabilities using capture-mark-recapture methods ( $\mathrm{n}=72$ individuals Bass Rock, $\mathrm{n}=$ 229 individuals Grassholm; 2010-2018) and applied sex-specific population projection matrices (PPMs) to quantify population-level effects. Tracked gannets wintered in a range of large marine ecosystems (LMEs): Canary Current LME (CCLME; $69 \%$ ), Celtic-Biscay Shelf LME (16\%), Iberian Coastal LME (8\%), North Sea LME (4\%) or Mediterranean LME (2\%). Migratory destination differed between the sexes: $90 \%$ of females vs. $57 \%$ of males wintered in the CCLME. Survival was similar between the sexes at Bass Rock (mean $\pm 95 \% \mathrm{CI}=0.951 \pm 0.053$ and $0.956 \pm 0.047$ for females and males, respectively). At Grassholm, there was evidence of slight sex differences in breeder survival: females had lower annual survival $(0.882 \pm 0.040)$ than males $(0.946 \pm 0.026)$. At Bass Rock, PPMs with no sex effect best fitted the observed population increase (1994-2014). Sexspecific PPMs fitted the population estimates for Grassholm (1995-2015). Our results reveal that female gannets are more likely to travel further than males to winter in the CCLME. This difference is unlikely due to morphological differences, unlike in other bird species. However, the reason for slightly higher over-winter female mortality at Grassholm is unclear.
\end{abstract}

KEY WORDS: Migratory $\cdot$ Seabird $\cdot$ Sex $\cdot$ Geolocator $\cdot$ Canary Current $\cdot$ Large Marine Ecosystem • Capture-mark-recapture

\section{INTRODUCTION}

Knowledge of a species' distribution throughout its annual cycle is crucial for understanding population dynamics and movement ecology as well as for con-

${ }^{*}$ Corresponding author: s.c.votier@exeter.ac.uk servation and protected area management (Marra et al. 2015). Many conservation efforts focus on protecting species during breeding, yet the non-breeding period usually represents the greater proportion of the annual cycle, and for some species, it is when the restricted. Authors and original publication must be credited. 
majority of mortality occurs (Barbraud \& Weimerskirch 2003, Klaassen et al. 2014). Understanding the incidence and implications of variation in migratory behaviour is thus an important area of ecological research.

Intra-specific, and particularly sex-specific, variation in migration is common in nature, and a sex difference in migration distance is considered to be the norm in birds, with females generally migrating further than males (Cristol et al. 1999). Unequal migration distances are usually attributed to differences in dominance (often mediated via body size) or habitat selection (due to differences in reproductive role or morphology), but the mechanisms are not well understood, and multiple factors are likely to contribute (Ketterson \& Nolan 1976, Cristol et al. 1999). Sex-specific differences in migration can also lead to sex-specific differences in mortality on the nonbreeding grounds, with important conservation implications (Weimerskirch \& Jouventin 1987). This may be due to differences in the costs of migration or differential risk of mortality during transit or on wintering grounds.

The emergence of animal-borne data loggers is advancing our understanding of the diversity of migratory behaviours (Block et al. 2011), the drivers of these differences (Fayet et al. 2017, Sherley et al. 2017) and their population-level consequences (Hewson et al. 2016). In the marine environment, tracking techniques have been applied to a wide range of vertebrate species, revealing detailed information on migration routes, range sizes, connectivity, habitat requirements, navigation and behaviour (Wakefield et al. 2009, Hammerschlag et al. 2011, Costa et al. 2012). Tracking of seabirds, in particular, has revealed a wide variety of migratory strategies, with some species remaining resident at breeding sites (Ainley et al. 1994), some dispersing into surrounding waters (Fayet et al. 2017) and others making huge long-haul flights, including the longest animal migration (Arctic tern Sterna paradisaed; Egevang et al. 2010). Sex differences in migration patterns are also common in seabirds (Phillips et al. 2009, Bosman et al. 2012), with males generally wintering closer to the colony than females (Phillips et al. 2017).

Many Atlantic breeding seabird species migrate to the Canary Current Large Marine Ecosystem (CCL$\mathrm{ME}$ ) off the coast of northwest Africa (Grecian et al. 2016). The CCLME is currently one of the most intensively fished areas of the planet and has the world's highest levels of illegal, unreported and unregulated (IUU) fisheries (Agnew et al. 2009). IUU fisheries represent $\sim 40 \%$ of the total catch for the region (Agnew et al. 2009) and do not implement bycatch reduction measures, so the risk to seabirds is potentially high (Anderson et al. 2011, Grémillet et al. 2015). The CCLME is also a region of high discarding rates (Zeller et al. 2018), making it attractive to scavenging seabirds or those that can supplement their diet with discards. Anecdotal information suggests high levels of seabird bycatch here, including reports of large numbers of dead northern gannets Morus bassanus (hereafter gannets) prepared for the human food chain (C. J. Camphuysen pers. comm.).

Gannets breed at large colonies in the North Atlantic and migrate to coastal shelf waters in winter. Some individuals are partial migrants and only move short distances away from the colony. For example, at Bass Rock in Scotland, the minimum migratory distance was $343 \mathrm{~km}$ and the maximum was $4654 \mathrm{~km}$ (Kubetzki et al. 2009). Gannets breeding in North America winter along the eastern seaboard of Canada and the USA, as far south as the Gulf of Mexico, with small numbers crossing the Atlantic to the CCLME (Fifield et al. 2014). Gannets from Europe, tracked from colonies in Norway in the north to France in the south, and also Icelandic gannets, winter across a broad latitudinal range from the North Sea to the CCLME (Kubetzki et al. 2009, Fort et al. 2012, Grémillet et al. 2015, Garthe et al. 2016). Despite having little sexual dimorphism (females are $\sim 7-8 \%$ heavier than males; Stauss et al. 2012, this study), gannets display sex-specific differences in foraging behaviour and distribution during the breeding season (Lewis et al. 2002, Stauss et al. 2012, Cleasby et al. 2015b). Sex differences in migration are not known for populations in North America (Fifield et al. 2014) or Europe (Stauss et al. 2012). However, sample sizes for such studies were small. If sex-specific spatial segregation does exist in non-breeding gannets as a result of differential migration, we predict there may be population-level impacts. Specifically, we hypothesize that the sex that predominates in the CCLME may be at higher risk of mortality from fisheries, given evidence of sex differences in bycatch rates in other species (Bugoni et al. 2011, Gianuca et al. 2017).

Here, we track the migration of male and female gannets using bird-borne geolocators (global location sensor loggers) from 2 large breeding colonies in the UK to test for sex differences in wintering destination - aided by larger sample sizes than in previous studies (Stauss et al. 2012, Fifield et al. 2014). We use December centroids to identify the core wintering range of each individual, which is then assigned to the nearest large marine ecosystem (LME; Sherman 1991). We also test for sex-specific differences in 
adult annual survival using capture-mark-recapture (CMR) of breeding birds from both colonies and use these survival estimates to construct population projection matrices (PPMs) for each colony to investigate population-level impacts.

\section{MATERIALS AND METHODS}

\subsection{Study sites and device deployment}

Light level loggers (MK5, MK15 and MK19; British Antarctic Survey) (hereafter geolocators) were deployed on breeding gannets at 2 colonies: Bass Rock, Scotland $\left(56^{\circ} 06^{\prime} \mathrm{N}, 02^{\circ} 36^{\prime} \mathrm{W}\right)$, in August 2010 and 2011 and Grassholm, Wales ( $51^{\circ} 43^{\prime} \mathrm{N}, 05^{\circ} 28^{\prime} \mathrm{W}$ ), in July and August 2009 to 2011. Bass Rock, the largest northern gannet colony in the world, had 75259 apparently occupied sites (AOSs) in 2014 (Murray et al. 2014) and Grassholm, the fourth largest colony in the world, had 36011 AOSs in 2015 (Murray et al. 2015b).

During July and August, adults with a chick were caught using a metal crook or noose attached to a pole. A geolocator was attached using cable ties to either a plastic leg ring or a metal British Trust for Ornithology ring that was fitted around the tarsus. The total weight of the device was less than $0.4 \%$ of body mass. Gannets cannot be reliably sexed by external morphology (Redman et al. 2002), so under UK Home Office Licence, blood was taken from the tarsal vein with a 23 gauge needle and a small aliquot used for DNA extraction and molecular sexing (Griffiths et al. 1998).

Gannets tend to show high nesting philopatry (Nelson 2002), allowing individuals that returned to the colonies in subsequent breeding seasons to be recaptured on the same nest in July and August 2011 and 2012 at Bass Rock and in July and August 2010 to 2014 at Grassholm. Although geolocators were deployed across multiple years, gannets showed high winter site fidelity (see Supplement 1 at www. int-res.com/articles/suppl/m622p191_supp.pdf; Grecian 2011, Fifield et al. 2014), so year was not considered in the analysis. For gannets that were tracked in multiple years, only the first year was used in all subsequent analyses.

\subsection{Geolocation analysis}

The geolocators measured light intensity every $60 \mathrm{~s}$ and recorded the maximum intensity for every $10 \mathrm{~min}$ period. Light level data were analysed using BASTrak software (British Antarctic Survey), resulting in 2 location estimates per day, with an estimated accuracy of $186 \pm 114 \mathrm{~km}$ (Phillips et al. 2004). A light level threshold of 16 and a sun elevation angle of $-4.0^{\circ}$ were used in processing data from all colonies, based on calibration data and previous knowledge of wintering areas (Kubetzki et al. 2009, Grecian 2011). Latitudes were compensated in relation to change in longitude to account for gannet movement. Errors in light intensity recordings can occur due to sensor shading or the presence of artificial light (Phillips et al. 2004). Any obviously erroneous fixes were omitted by manually filtering the data in ArcMap (ESRI). Data were then smoothed twice to further reduce errors in mean location estimates (Phillips et al. 2004).

\subsection{Defining non-breeding area}

Locations from 1 to 31 December were used to determine non-breeding sites since all birds stayed in a restricted area within this period, as in previous geolocation studies of gannets (Kubetzki et al. 2009, Fort et al. 2012). The centroid (mean latitude and longitude) in December was calculated for each bird to assign it to an LME (Sherman 1991). If a centroid fell outside any LME (e.g. was inland), it was assigned to the nearest LME by straight-line distance. The LME concept was developed as a tool for ecosystem-based conservation. LMEs encompass large ocean regions from coasts to continental shelf boundaries and the outer margins of major current systems and are characterised by distinct hydrography, bathymetry, productivity and trophic interactions (Sherman 1991).

\subsection{Statistical analysis of sex-specific differences in non-breeding area}

Gannets wintered in 5 different LMEs. Since sample sizes in some LMEs were small and we predicted a priori that birds in the CCLME were at greatest risk of being bycaught in fisheries, for analysis we split birds into 2 groups: those wintering in the CCLME and those that wintered elsewhere (North Sea, Celtic-Biscay Shelf, Iberian Coastal and Mediterranean Sea LMEs). We used a generalised linear model (GLM), specified in the R statistical software (R Core Team 2016), to test for the effects of sex, colony and their interactions on the binary response variable of wintering location (i.e. CCLME or non-CCLME). The 
maximal model was fitted, and terms were then removed by sequential elimination, using likelihood ratios to test for significant changes to the model fit. We calculated marginal $\mathrm{R}^{2}$ using the MuMIn package (version 1.42.1; Barto 2018) to assess the predictive power of the final model.

\subsection{Survival analysis}

To estimate annual over-winter survival probability, we marked birds with an individually identifiable, multi-layered impact acrylic leg ring engraved with a 4-digit alphanumeric code (http://colour-rings . eu/). At Bass Rock, 53 breeding birds were marked in 2010 and 19 were marked in 2015 (total $=72$ ). On Grassholm, between 20 and 36 breeding birds were marked each year between 2010 and 2017 (total = 229). During return visits to Bass Rock between 2011 and 2016 and to Grassholm between 2011 and 2018, searches were made for birds with engraved rings. Resightings (rather than recaptures) were used to build annual encounter histories for marked birds, and CMR models (Lebreton et al. 1992) were specified in the program MARK (version 8.2; White \& Burnham 1999) to estimate apparent survival $(\phi)$ and recapture $(p)$ probabilities.

We used U-CARE (Choquet et al. 2009) to test the goodness of fit (GOF) of a fully sex- and time-dependent Cormack-Jolly-Seber (CJS) model (the global model used in open populations and for multiple census estimates) for each colony. For Bass Rock, there was no evidence of transience (the presence of individuals that permanently leave the population after being marked and released; $z=0.36,2$-sided test, $p=$ 0.719 ) or trap dependence (where the probability of recapture is not independent between occasions; $z=$ $-1.41,2$-sided test, $\mathrm{p}=0.159$ ), suggesting that the CJS model fitted the data well (overall GOF: $\chi^{2}{ }_{10}=$ $5.61, p=0.847$ ). To account for remaining extra-binomial variation, we used a variance inflation factor $(\hat{c})$ of 1.007 for Bass Rock. For Grassholm, the CJS model did not describe the data well $\left(\chi_{47}^{2}=85.96, p<0.001\right)$, and there was evidence of trap dependence $(z=$ $-5.91,2$-sided test, $\mathrm{p}<0.001)$ but not transience $(z=$ $1.76,2$-sided test, $p=0.078$ ). The signed statistics for trap dependence (TEST2.CT) suggest trap happiness, rather than trap shyness, in both males $(z=$ -3.66, p < 0.001) and females $(z=-4.70, \mathrm{p}<0.001)$. The Grassholm data were therefore split for trap dependence in U-CARE, and a 2-class time since marking (TSM) structure was used to model recapture (Pradel 1993), with the first class set as a con- stant. After accounting for trap dependence in the Grassholm dataset, a c of 0.901 was calculated from the U-CARE output, suggesting underdispersion. We set $\hat{\mathrm{c}}=1$, as recommended for cases where $\hat{\mathrm{c}}<1$ (White et al. 2001). For Grassholm, we initially included a Sex $\times$ Time interaction term for recapture for the second TSM class, but several model parameters were not estimable, so we simplified recapture structure to a maximum of Sex + Time. For both Bass Rock and Grassholm, model averaging was performed across the full model set to calculate weighted means $( \pm 95 \% \mathrm{CI})$ of parameter estimates (White et al. 2001).

\subsection{Population projection models}

To predict the population-level consequences of our estimates of adult mortality, we constructed 2sex, age-structured matrix population models (Caswell 2001; see Supplement 3 for details). We modelled adult survival rates as stochastic to account for uncertainty in our estimates of this parameter. Although the other life history parameters used in our model would not have been estimated without uncertainty in reality, we modelled them as deterministic to allow for clearer comparisons between the different scenarios for sex-specific adult survival. The uncertainty in our population projections will therefore underestimate the true uncertainty in population growth. Juvenile (first year) survival (0.542) and 3 immature stages (years 2-4) with survival rates of $0.779,0.859$ and 0.863 , respectively, were specified based on ring recovery data from Bass Rock (Wanless et al. 2006). All adults were assumed to be breeding from age 5 (Nelson 2002, Wanless et al. 2006). Fecundity was set at 0.72 , an average from studies of breeding success at Bass Rock, Bempton and Ailsa Craig (Nelson 2002, Wanless 2002, Wanless et al. 2006). We used starting population sizes from 1994 or 1995 of 26277 and 34397 pairs for Grassholm and Bass Rock, respectively, projected the population forward to 2030 and compared our models to observed nest counts from 1999, 2004, 2009, and 2014 or 2015 (Mitchell et al. 2004, Murray et al. 2014, 2015a,b). Based on the results from our survival analysis (see Section 3), 4 different adult survival scenarios were modelled: (1) a Bass Rock model using random samples from the sex-specific model-averaged survival estimates for that colony, (2) a Grassholm model applying random samples from the model-averaged survival estimate for males to both sexes, (3) a Grassholm model using random samples from the 
sex-specific model-averaged survival rates and (4) a Grassholm model applying random samples from the model-averaged survival estimate for females to both sexes. In each case, we incorporated parameter uncertainty on the adult survival rates by drawing 100000 samples from a beta distribution using samples from the time-specific estimates $\pm \mathrm{SE}$ (see Supplement 3 for details). We report the mean population growth rate $(\lambda)$ and bootstrapped $95 \%$ CI $(2.5$ th and 97.5th percentiles) from 100000 model runs. Projections should be viewed with caution since juvenile and immature survival is estimated from ring recovery data from 1959 to 2002 from Bass Rock only (Wanless et al. 2006).

\section{RESULTS}

\subsection{Gannet winter distribution by LME}

Geolocators were successfully retrieved and downloaded for 49 known-sex birds: 30 from Bass Rock (17 males, 13 females) and 19 from Grassholm (13 males, 6 females). December centroids for $69 \%$ of individuals were in the CCLME, $16 \%$ in the Celtic-Biscay Shelf LME, $8 \%$ in the Iberian Coastal LME, $4 \%$ in the North Sea LME and $2 \%$ in the Mediterranean LME (Table 1, Fig. 1).

\subsection{Gannet migration by sex and colony}

The vast majority of females (90\% of 19), but just over half of the males ( $57 \%$ of 30$)$, wintered in the CCLME (Fig. 1). There was a significant effect of sex on use of the CCLME (GLM: $\chi^{2}{ }_{1}=53.84, p=0.01$ ) but

Table 1. Wintering areas (by large marine ecosystem, LME) of male and female northern gannets Morus bassanus tracked from Bass Rock and Grassholm, UK

\begin{tabular}{|c|c|c|c|c|c|c|}
\hline \multirow{2}{*}{$\begin{array}{l}\text { Colony/ } \\
\text { Sex }\end{array}$} & \multicolumn{5}{|c|}{$\longrightarrow$ LME wintering area $(\%)$} & \multirow[t]{2}{*}{ Total } \\
\hline & $\begin{array}{l}\text { Canary } \\
\text { Current }\end{array}$ & $\begin{array}{c}\text { Celtic-Biscay } \\
\text { Shelf }\end{array}$ & $\begin{array}{l}\text { Iberian } \\
\text { Coastal }\end{array}$ & $\begin{array}{l}\text { Mediter- } \\
\text { ranean }\end{array}$ & $\begin{array}{l}\text { North } \\
\text { Sea }\end{array}$ & \\
\hline \multicolumn{7}{|l|}{ Bass Rock } \\
\hline Female & 92 & 8 & 0 & 0 & 0 & 13 \\
\hline Male & 53 & 18 & 18 & 6 & 6 & 17 \\
\hline Colony \% & 70 & 13 & 10 & 3 & 3 & 30 \\
\hline \multicolumn{7}{|l|}{ Grassholm } \\
\hline Female & 83 & 17 & 0 & 0 & 0 & 6 \\
\hline Male & 62 & 23 & 8 & 0 & 8 & 13 \\
\hline Colony \% & 68 & 21 & 5 & 0 & 5 & 19 \\
\hline Overall \% & 69 & 16 & 8 & 2 & 4 & 49 \\
\hline
\end{tabular}

no effect of colony $\left(\chi^{2}{ }_{1}=0.03, \mathrm{p}=0.86\right)$ and no interaction $\left(\chi^{2}{ }_{1}=0.52, p=0.47\right)$. Sex explained $20.5 \%$ of the variation in wintering location.

\subsection{Adult survival probability}

At Bass Rock, 72 breeding gannets (36 males, 36 females) were marked, of which 67 (33 males, 34 females) were resighted at least once (see Supplement 2 at www.int-res.com/articles/suppl/m622p191 _supp.pdf). While the top model included constant survival, the model set included support for effects of time and sex on survival. There was support for sex- and time-dependent resighting probability in the top models (Table 2). Model averaging therefore resulted in separate survival and resighting probabilities for males and females in each year. Model-averaged annual survival estimates varied from 0.933 (95\% CI: $0.753-0.985)$ to $0.974(0.864-$ $0.995)$ for males and $0.925(0.735-0.982)$ to 0.970 (0.851-0.995) for females. Mean (SD) survival for males and females was 0.956 (0.047) and 0.951 (0.053), respectively. Resighting probabilities varied between years, from 0.623 (95\% CI: $0.451-0.770$ ) to 0.963 (0.851-0.991) for males and from 0.548 $(0.385-0.702)$ to $0.950(0.815-0.988)$ for females (Fig. S2 in Supplement 2).

At Grassholm, 229 breeding gannets (125 males, 104 females) were marked, of which 170 (99 males, 71 females) were resighted at least once (see Supplement 2). The top model included a sex effect on survival and a time effect on resighting probability (Table 2). Model-averaged annual survival estimates varied from 0.944 (95\% CI: $0.859-0.979)$ to 0.947 (0.866-0.981) for males and from 0.877 (0.763-0.940) to $0.887(0.783-0.944)$ for females. Mean (SD) survival for males and females was $0.946(0.026)$ and $0.882(0.040)$, respectively. Resighting probability varied between years, from 0.073 (95\% CI: 0.006-0.497) to $0.719(0.667-0.765)$ for males and from $0.065(0.005-0.487)$ to $0.719(0.667-0.765)$ for females (Fig. S2).

\subsection{Population projection models}

The Bass Rock survival estimates led to a projected population increase that closely matched the observed trend in breeding pairs between 1994 and 2014 (Fig. $2 \mathrm{~A}) ; \lambda=1.044$ (95\% CI: $0.999-$ 

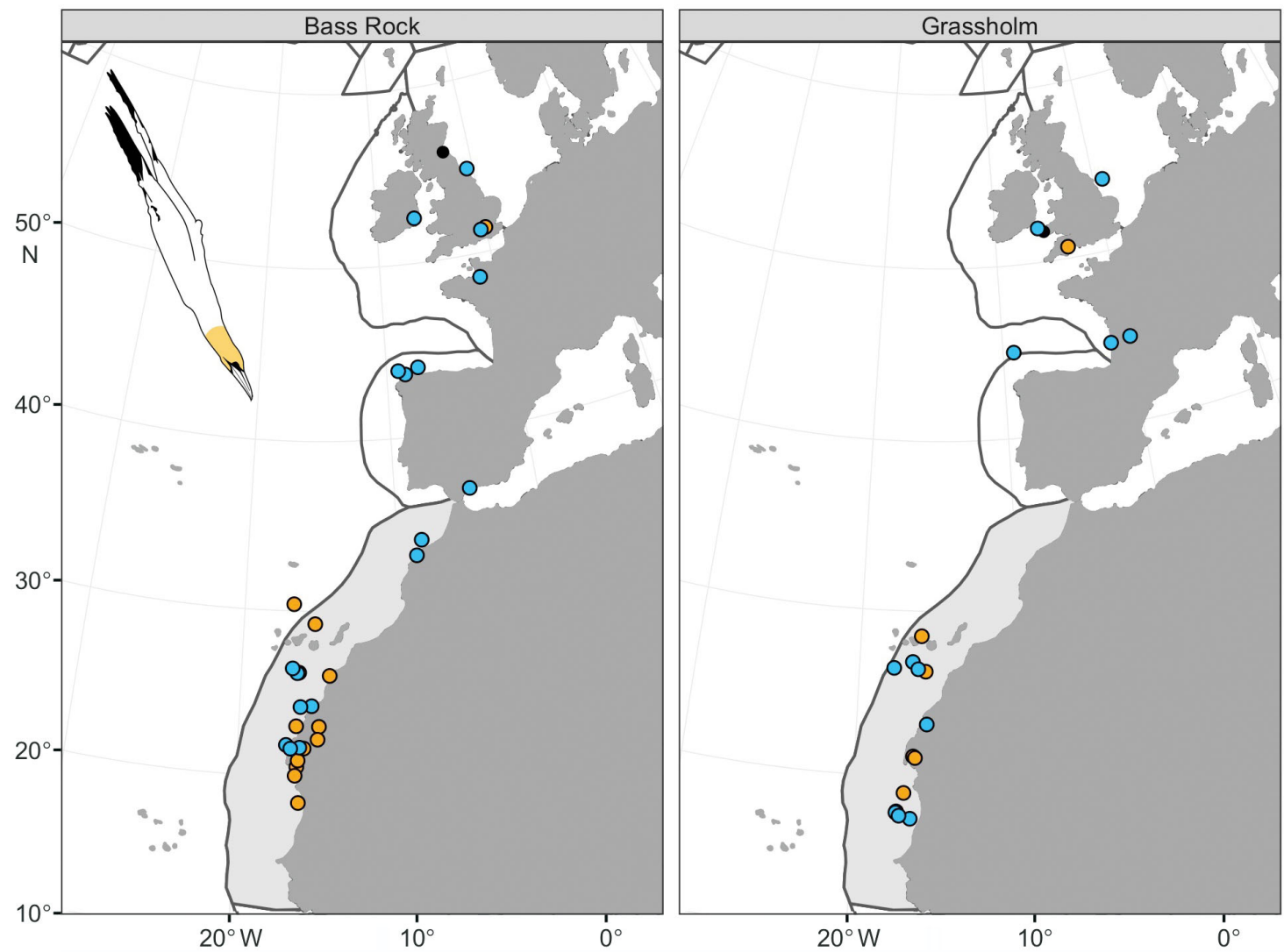

Fig. 1. Centroids of locations in December of male (blue) and female (orange) northern gannets tracked with geolocators from Bass Rock ( $\mathrm{n}=30 ; 17$ males and 13 females) and Grassholm ( $=19 ; 13$ males and 6 females during 2010 to 2014). Colony locations are marked with a solid black circle. Solid black lines mark borders of large marine ecosystems. Shaded area represents the Canary Current Large Marine Ecosystem

Table 2. Top 5 models (ranked by QAIC c $_{\text {) }}$ of survival and resighting probabilities of northern gannets Morus bassanus breeding on Bass Rock, Scotland (2010-2016), and Grassholm, Wales (2010-2018), based on capture-mark-recapture analysis. Bass Rock variance inflation factor $(\hat{\mathrm{c}})=1.007$; Grassholm $\hat{\mathrm{c}}=$ 1.000. Model subscripts relate to effects fitted to survival $(\phi)$ and resighting $(p)$ probabilities ( $s$ : sex dependence; $t$ : time dependence; $c$ : constant). For Grassholm, models have a 2-class time since marking structure for recapture to account for trap dependence (a2). QAIC : quasi-likelihood adjusted Akaike's information criterion $\left(\mathrm{AIC}_{\mathrm{c}}\right)_{i}, \mathrm{QAIC}_{\mathrm{c}}$ : difference in $\mathrm{QAIC}_{\mathrm{c}}$ compared to the top model; QDeviance: quasi-likelihood adjusted deviance

\begin{tabular}{|lccccccc|}
\hline \multicolumn{2}{|c}{ Model } & QAIC $_{\mathrm{c}}$ & $\mathrm{QAIC}_{\mathrm{c}}$ & $\begin{array}{c}\mathrm{AIC}_{\mathrm{c}} \\
\text { weights }\end{array}$ & $\begin{array}{c}\text { Model } \\
\text { likelihood }\end{array}$ & $\begin{array}{c}\text { No. of } \\
\text { parameters }\end{array}$ & QDeviance \\
\hline Bass Rock & & & & & & \\
1 & $\phi_{c} p_{s+t}$ & 328.31 & 0 & 0.243 & 1 & 8 & 58.73 \\
2 & $\phi_{c} p_{t}$ & 328.65 & 0.34 & 0.205 & 0.843 & 7 & 61.20 \\
3 & $\phi_{t} p_{s+t}$ & 329.46 & 1.15 & 0.137 & 0.563 & 12 & 51.21 \\
4 & $\phi_{t} p_{t}$ & 329.85 & 1.54 & 0.112 & 0.462 & 11 & 53.80 \\
5 & $\phi_{s} p_{t}$ & 330.11 & 1.80 & 0.099 & 0.406 & 8 & 60.54 \\
Grassholm & & & & & & \\
1 & $\phi_{s} p_{a 2-c / t}$ & 1127.57 & 0 & 0.563 & 1 & 10 & 682.44 \\
2 & $\phi_{s} p_{a 2-c / s+t}$ & 1129.39 & 1.821 & 0.227 & 0.402 & 11 & 682.19 \\
4 & $\phi_{c} p_{a 2-c / s+t}$ & 1131.18 & 3.605 & 0.093 & 0.165 & 10 & 686.05 \\
5 & $\phi_{c} p_{a 2-c / t}$ & 1133.16 & 5.585 & 0.035 & 0.061 & 9 & 690.10 \\
3 & $\phi_{s+t} p_{a 2-c / s+t}$ & 1133.24 & 5.667 & 0.033 & 0.059 & 18 & 671.30 \\
\hline
\end{tabular}

1.068), resulting in a projected population of 80928 (33880-128547) pairs in 2014 (observed count = 75259 AOSs) and 160456 (33471$369060)$ pairs by 2030. For Grassholm scenario 1 , using the male survival estimate $(0.946)$ yielded $\lambda=$ $1.033(1.002-1.055)$, and the projected population increased faster than the observed trend; it was 51924 (27624-80 722) pairs in 2015 (observed count $=36011$ AOSs) and 84459 (28628-179946) pairs by 2030 . The $95 \%$ CIs did not overlap 1, and the population was predicted to increase under $98.1 \%$ of simulations using these parameter values (Fig. 2B). For Grassholm scenario 2, using the sex-specific survival rates $(0.946$ and 0.882$)$ led to a projected population increase that matched the observed trend between 

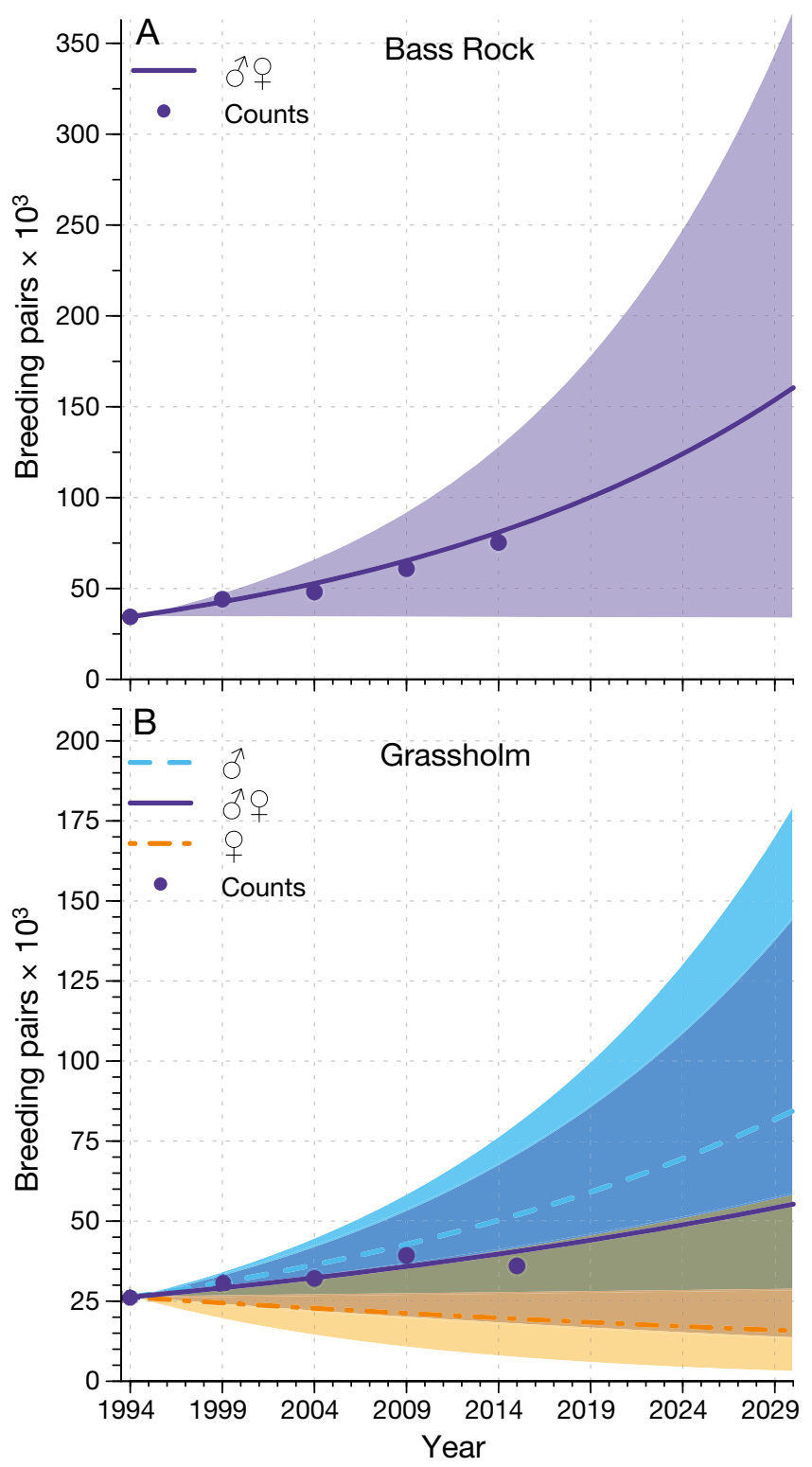

Fig. 2. Population projections between 1994 and 2030 for northern gannets Morus bassanus at (A) Bass Rock using sexspecific $\left(\sigma^{\prime}\right.$ of) adult survival rates and (B) Grassholm under 3 adult survival scenarios: (1) using male $\left(\sigma^{7}\right)$ survival rates for both sexes (dashed line, light blue polygon), (2) using sexspecific ( $0^{\prime}$ ) ) survival rates (solid line, dark blue polygon), and (3) using female (o) survival rates for both sexes (dot-dashed line, orange polygon). Coloured polygons show the range of the $95 \%$ quantiles. See Table S6 in Supplement 3 at www.intres.com/articles/suppl/m622p191_supp.pdf for model parameters. Dark blue points show the observed population sizes from 5 censuses made between 1994 and 2014 at Bass Rock and between 1994 and 2015 at Grassholm

1994 and 2015 (Fig. 2B); $\lambda=1.021 \quad(95 \%$ CI: $0.982-1.049)$, and the projected population was 40555 (177 93-71 090) pairs in 2015 (observed count $=36011 \mathrm{AOSs})$ and 55292 (13468-144 724) pairs by
2030. Finally, for Grassholm scenario 3, when the female survival estimate (0.882) was applied to both sexes, $\lambda=0.986(0.941-1.022)$, the mean population size was predicted to decrease under $73.6 \%$ of simulations to 19491 (7310-41924) pairs in 2015 and 15746 (2931-58529) pairs in 2030 (Fig. 2B).

\section{DISCUSSION}

Our results show that adult gannets tracked from 2 UK colonies have a diversity of migratory behaviours, wintering in a broad latitudinal range from the North Sea south to West Africa (Table 1, Fig. 1). However, $69 \%$ of birds had their core wintering range in the CCLME, highlighting the importance of this region as a hotspot for gannets in the non-breeding season. We also found that a significantly higher proportion of females $(90 \%)$ than males $(57 \%)$ wintered in the CCLME. Moreover, female survival was significantly lower for birds from Grassholm. However, we found no significant sex effects on demography at Bass Rock, even though $92 \%$ of females wintered in the CCLME.

\subsection{Use of the CCLME as a wintering area}

Overall, we found that $69 \%$ of tracked gannets wintered in the CCLME in 2010 to 2014, which is higher than in previous studies of gannet populations in northern Europe. During 2002 to 2004, only $45 \%$ of adults from Bass Rock wintered in the CCLME (Kubetzki et al. 2009), as did only $47 \%$ of gannets from Iceland in 2010 to 2011 (Garthe et al. 2012) and $24 \%$ of adults from the Sept-Iles Archipelago, France, in 2010 to 2012 (Grémillet et al. 2015). Only $7 \%$ of gannets breeding in Newfoundland, Canada, made trans-Atlantic migrations to winter in the CCLME during 2005 to 2010 (Fifield et al. 2014).

While it is clear that the CCLME is an important wintering destination for gannets, it is unclear why there is such strong variation among colonies and over time. Inter-colony differences could potentially arise because of latitudinal variation in migration distance (Fort et al. 2012). This seems unlikely, however, since the most southerly breeding gannets in France have the lowest proportion of birds wintering in the CCLME (Grémillet et al. 2015). Instead, this difference may reflect a sex bias in tracked birds from different colonies if the sex differences reported here are widespread. An increase in the proportion of birds from Bass Rock that win- 
ter in the CCLME could point towards a change in migratory behaviour. Until the late 1990s, ring recoveries and at-sea observations suggested that most British breeding gannets tended to winter close to their colonies, with only small numbers migrating to the coast of West Africa (Nelson 2002, Wanless 2002). Moreover, this was not a recovery bias, as rings from many other seabirds were recovered in West Africa (Wernham et al. 2002). A shift towards the CCLME wintering site may be due to reductions in prey availability further north (Heath 2005), increased foraging opportunities in the CCLME (Zeller et al. 2018) or variation in migration distance driven by density dependence (Matthysen 2005, Fayet et al. 2017).

\subsection{Sex-specific differences in use of the CCLME}

Females were significantly more likely to travel to the CCLME than males (Table 1, Fig. 1). The 3 main hypotheses for differential migration are (1) body size, such that the sexes are better adapted to different conditions; (2) dominance, where one sex is competitively excluded from a particular area; and (3) arrival time, where one sex benefits from early arrival at the breeding site so undertakes a shorter migration (Newton 2008). As male and female gannets are similar in linear dimensions and females only average around $8 \%$ heavier (Stauss et al. 2012), there is little support for the body size hypothesis. Although there is no clear evidence of other sex differences in dominance (Nelson 2002), males may be more likely to scavenge at fishing boats than females where competition is high (Stauss et al. 2012, Votier et al. 2013). This provides limited support for the dominance hypothesis, but note in other years, there are no sex differences in gannet scavenging behaviour during breeding season (Patrick et al. 2015). At the start of the breeding season, male gannets return to the colony before females to establish and defend territories (Nelson 2002), and male Cape gannets Morus capensis stay close to the colony throughout the year to maintain the breeding territory (Pistorius et al. 2015). However, there was no difference in the timing of return to Bass Rock of gannets wintering in different areas (Kubetzki et al. 2009; although this was examined with respect to wintering location only and not sexspecific variability), so support for the arrival time hypothesis is mixed. Therefore, the reasons for sexspecific differences in migration strategies in this species are currently unclear.

\subsection{Annual survival of adult gannets}

On Grassholm, female gannets had lower survival $(\sim 0.88)$ than males $(\sim 0.95)$; this represents more than double the rate of mortality in females $(12 \%)$ than males $(5 \%)$. However, resighting probability and sample sizes for both sexes were relatively low at Grassholm, leading to large confidence intervals, and there was also evidence of trap dependence, so we should interpret these values with some caution. Nevertheless, the mean trend in the sex-specific PPMs provided a good fit to the observed population trends (Fig. 2B), suggesting the data may be a fair representation of the actual values and that there is indeed a sex-specific difference in demography. Male and female gannets on Bass Rock had very similar survival ( $\sim .96$ and 0.95 , respectively). These values are higher than estimates based on ringing recovery of adults from Bass Rock (0.916, $95 \%$ CI: 0.910-0.922; Wanless et al. 2006) but fitted well with the observed population growth rate (Fig. 2A).

\subsection{Projected change in gannet populations}

The gannet population on Grassholm is increasing slowly $(\lambda=1.021)$ and is predicted to reach 55292 (13 468-144 724) pairs by 2030. Therefore, the currently low female survival is not sufficient to prevent population growth. However, if both sexes shared the same low annual survival, our simulations suggest the population would decline with $>70 \%$ probability to 15746 (2931-58529) pairs by 2030. Note, however, the very large confidence intervals associated with our projection, incorporating both negative and positive forecasts (Fig. 2). This uncertainty is related to the large error terms around the survival estimates, highlighting the importance of endeavouring to obtain the most precise estimates. The Bass Rock population is increasing more rapidly $(\lambda=1.044)$ and is predicted to reach 160456 (33471-369060) pairs by 2030 (Fig. 2). However, an increase of this magnitude is in reality highly unlikely since there is now limited space for gannets to breed on Bass Rock (Murray et al. 2015a).

\subsection{Sex-specific differences in mortality and migration}

Sex biases in fisheries bycatch have been found in several seabird species (Bugoni et al. 2011, Gianuca et al. 2017) and are generally caused by sexual seg- 
regation at sea (Gianuca et al. 2017). It is possible that the slight sex differences in survival found here are a consequence of sex differences in bycatch, given the high levels of seabird bycatch in the CCLME (Zeeberg et al. 2006, Grémillet et al. 2015), which includes large numbers of gannets (C. J. Camphuysen pers. comm.). However, we only found an effect on survival of female gannets from Grassholm, even though the vast majority of females from Bass Rock (92\%) also wintered in the CCLME. The reason for this difference is unclear but may be related to conditions at the 2 colonies during the breeding season or perhaps differences in foraging behaviour or fine-scale distribution during the winter period. Gannets at Grassholm scavenge at fishing boats much more than those from Bass Rock (Votier et al. 2010, 2013, Cleasby et al. 2015b), and adult gannets are highly repeatable in their associations with fishing vessels during the breeding season (Patrick et al. 2015). Therefore, such colony-specific differences in attraction to fishing vessels could potentially be retained year-round. Better understanding of this would require a much more detailed knowledge of seabird bycatch rates and seabird-fishery interactions in the CCLME. One possible approach could be to compare seabird movements from bird-borne trackers with fishery distributions from automatic identification system data (Kroodsma et al. 2018).

As well as the high risk of bycatch, fishery interactions may have deleterious nutritional costs because discards may be low in lipids (Grémillet et al. 2008) and have a high contaminant burden (Arcos et al. 2002) compared with naturally caught pelagic fish. Nevertheless, while discards may represent junk food for developing chicks (Grémillet et al. 2008), virtually nothing is known about whether this is the case for other members of the population.

Gannets face a range of threats throughout their annual cycle, including marine pollution (Votier et al. 2011a, Montevecchi et al. 2012), renewable energy production (Furness et al. 2013, Cleasby et al. 2015a) and declining food availability as a result of fisheries exploitation or environmental change (Montevecchi \& Myers 1997). Further work is required to quantify these potential impacts across their annual cycle and also across different age classes, which have quite different movement strategies (Votier et al. 2011b, 2017, Grecian et al. 2018).

Our study provides evidence of sex differences in seabird migration, with more female gannets than males wintering off West Africa. Moreover, these differences are unlikely to be related to body size in this only slightly dimorphic species. We further highlight the importance of the CCLME as a hotspot for seabird diversity (Grecian et al. 2016), particularly its utilisation by female gannets. However, high levels of bycatch and fisheries target stock exploitation could explain the lower survival of female gannets, although the pattern was not consistent across colonies. In addition, the results presented here demonstrate the importance of accounting for sexspecific differences in survival when predicting population trajectories. We also indicate the potential for non-breeding areas to influence population dynamics by affecting survival and highlight the importance of a year-round approach to species monitoring, particularly for long-distance migrants.

Acknowledgements. We thank the RSPB for permission to work on Grassholm as well as Venturejet and Thousand Islands Expeditions for providing safe boat access to the island. Various people helped during fieldwork on Grassholm (Dimas Gianuca, Tommy Clay, Jen Tyler, Mel Wells, Calum Laver, James Waggitt, Claudia Stauss, Sam Patrick, Sam Cox, Kylie Scales, Nicola Childs, Pearl Costello, Matt Carter, Matt Nicholson, Kelly Atkins, Rhiannon Austin, Laura Zango, Kirsten Archibald and Jacob González-Solís) and Bass Rock (Charlotte Dooley, Chiara Rubbianesi, Elspeth Robinson and Chris Gilbert). We thank Sir Hew Hamilton-Dalrymple and the Scottish Seabird Centre, North Berwick, for access to Bass Rock and Maggie Sheddan and the Dale family for logistic support. The work was funded by the Natural Environment Research Council (Standard Research Grant NE/H007466/1) and donations from Evan Fountain (In Memoriam donations for Issy Fountain) and Mike Matthewson.

\section{LITERATURE CITED}

Agnew DJ, Pearce J, Pramod G, Peatman T, Watson R, Beddington JR, Pitcher TJ (2009) Estimating the worldwide extent of illegal fishing. PLOS ONE 4:e4570

* Ainley DG, Ribic CA, Fraser WR (1994) Ecological structure among migrant and resident seabirds of the Scotia-Weddell Confluence region. J Anim Ecol 63:347-364

Anderson ORJ, Small CJ, Croxall JP, Dunn EK, Sullivan BJ, Yates O, Black A (2011) Global seabird bycatch in longline fisheries. Endang Species Res 14:91-106

Arcos JM, Ruiz X, Bearhop S, Furness RW (2002) Mercury levels in seabirds and their fish prey at the Ebro Delta (NW Mediterranean): the role of trawler discards as a source of contamination. Mar Ecol Prog Ser 232:281-290

* Barbraud C, Weimerskirch H (2003) Climate and density shape population dynamics of a marine top predator. Proc R Soc B 270:2111-2116

Barto K (2018) MuMIn: multi-model inference. R package version 1.42.1. https://CRAN.R-project.org/package= MuMIn

Block BA, Jonsen ID, Jorgensen SJ, Winship AJ and others (2011) Tracking apex marine predator movements in a dynamic ocean. Nature 475:86-90

*Bosman DS, Vercruijsse HJP, Stienen EWM, Vincx M, de Neve L, Lens L (2012) Effects of body size on sex-related 
migration vary between two closely related gull species with similar size dimorphism. Ibis 154:52-60

Bugoni L, Griffiths K, Furness RW (2011) Sex-biased incidental mortality of albatrosses and petrels in longline fisheries: differential distributions at sea or differential access to baits mediated by sexual size dimorphism? J Ornithol 152:261-268

Caswell H (2001) Matrix population models: construction, analysis, and interpretation. Sinauer Associates, Sunderland, MA

Choquet R, Lebreton JD, Gimenez O, Reboulet AM, Pradel R (2009) U-CARE: utilities for performing goodness of fit tests and manipulating CApture-REcapture data. Ecography 32:1071-1074

Cleasby IR, Wakefield ED, Bearhop S, Bodey TW, Votier SC, Hamer KC (2015a) Three-dimensional tracking of a wide-ranging marine predator: flight heights and vulnerability to offshore wind farms. J Appl Ecol 52:1474-1482

Cleasby IR, Wakefield ED, Bodey TW, Davies RD and others (2015b) Sexual segregation in a wide-ranging marine predator is a consequence of habitat selection. Mar Ecol Prog Ser 518:1-12

Costa DP, Breed GA, Robinson PW (2012) New insights into pelagic migrations: implications for ecology and conservation. Annu Rev Ecol Evol Syst 43:73-96

Cristol DA, Baker MB, Carbone C (1999) Differential migration revisited: latitudinal segregation by age and sex class. In: Nolan V Jr, Ketterson ED, Thompson CF (eds) Current ornithology, Vol 15. Springer, New York, NY, p 33-88

Egevang C, Stenhouse IJ, Phillips RA, Petersen A, Fox JW, Silk JRD (2010) Tracking of Arctic terns Sterna paradisaea reveals longest animal migration. Proc Natl Acad Sci USA 107:2078-2081

Fayet AL, Freeman R, Anker-Nilssen T, Diamond A and others (2017) Ocean-wide drivers of migration strategies and their influence on population breeding performance in a declining seabird. Curr Biol 27:3871.e3-3878.e3

Fifield D, Montevecchi WA, Garthe S, Robertson GJ, Kubetzki U, Rail J (2014) Migratory tactics and wintering areas of northern gannets (Morus bassanus) breeding in North America. Ornithol Monogr 79:1-63

Fort J, Pettex E, Tremblay Y, Lorentsen SH and others (2012) Meta-population evidence of oriented chain migration in northern gannets (Morus bassanus). Front Ecol Environ 10:237-242

Furness RW, Wade HM, Masden EA (2013) Assessing vulnerability of marine bird populations to offshore wind farms. J Environ Manage 119:56-66

* Garthe S, Ludynia K, Hüppop O, Kubetzki U, Meraz JF, Furness RW (2012) Energy budgets reveal equal benefits of varied migration strategies in northern gannets. Mar Biol 159:1907-1915

Garthe S, Hallgrimsson GT, Montevecchi WA, Fifield D, Furness RW (2016) East or west? Migration routes and wintering sites of northern gannets Morus bassanus from south-eastern Iceland. Mar Biol 163:151

Gianuca D, Phillips RA, Townley S, Votier SC (2017) Global patterns of sex- and age-specific variation in seabird bycatch. Biol Conserv 205:60-76

Grecian WJ (2011) Factors influencing the marine spatial ecology of seabirds: implications for theory, conservation and management. $\mathrm{PhD}$ thesis, University of Plymouth

Grecian WJ, Witt MJ, Attrill MJ, Bearhop S and others (2016) Seabird diversity hotspot linked to ocean produc- tivity in the Canary Current Large Marine Ecosystem. Biol Lett 12:20160024

*Grecian WJ, Lane JV, Michelot T, Wade HM, Hamer KC (2018) Understanding the ontogeny of foraging behaviour: insights from combining marine predator biologging with satellite-derived oceanography in hidden Markov models. J R Soc Interface 15:20180084

Grémillet D, Pichegru L, Kuntz G, Woakes AG, Wilkinson S, Crawford RJM, Ryan PG (2008) A junk-food hypothesis for gannets feeding on fishery waste. Proc R Soc B 275: 1149-1156

* Grémillet D, Peron C, Provost P, Lescroel A (2015) Adult and juvenile European seabirds at risk from marine plundering off West Africa. Biol Conserv 182:143-147

Griffiths R, Double MC, Orr K, Dawson RJG (1998) A DNA test to sex most birds. Mol Ecol 7:1071-1075

*Hammerschlag N, Gallagher AJ, Lazarre DM (2011) A review of shark satellite tagging studies. J Exp Mar Biol Ecol 398:1-8

* Heath MR (2005) Changes in the structure and function of the North Sea fish foodweb, 1973-2000, and the impacts of fishing and climate. ICES J Mar Sci 62:847-868

*Hewson CM, Thorup K, Pearce-Higgins JW, Atkinson PW (2016) Population decline is linked to migration route in the common cuckoo. Nat Commun 7:12296

Ketterson ED, Nolan V (1976) Geographic variation and its climatic correlates in the sex ratio of eastern-wintering dark-eyed juncos (Junco hyemalis hyemalis). Ecology 57: 679-693

Klaassen RHG, Hake M, Strandberg R, Koks BJ and others (2014) When and where does mortality occur in migratory birds? Direct evidence from long-term satellite tracking of raptors. J Anim Ecol 83:176-184

Kroodsma DA, Mayorga J, Hochberg T, Miller NA and others (2018) Tracking the global footprint of fisheries. Science 359:904-908

Kubetzki U, Garthe S, Fifield D, Mendel B, Furness RW (2009) Individual migratory schedules and wintering areas of northern gannets. Mar Ecol Prog Ser 391: $257-265$

K Lebreton JD, Burnham KP, Clobert J, Anderson DR (1992) Modeling survival and testing biological hypotheses using marked animals: a unified approach with case studies. Ecol Monogr 62:67-118

*Lewis S, Benvenuti S, Dall-Antonia L, Griffiths R and others (2002) Sex-specific foraging behaviour in a monomorphic seabird. Proc R Soc B 269:1687-1693

* Marra PP, Cohen EB, Loss SR, Rutter JE, Tonra CM (2015) A call for full annual cycle research in animal ecology. Biol Lett 11:20150552

Matthysen E (2005) Density-dependent dispersal in birds and mammals. Ecography 28:403-416

Mitchell PI, Newton SF, Ratcliffe N, Dunn TE (2004) Seabird populations of Britain and Ireland. T \& AD Poyser, London

Montevecchi WA, Myers RA (1997) Centurial and decadal oceanographic influences on changes in northern gannet populations and diets in the north-west Atlantic: implications for climate change. ICES J Mar Sci 54:608-614

* Montevecchi W, Fifield D, Burke C, Garthe S, Hedd A, Rail JF, Robertson G (2012) Tracking long-distance migration to assess marine pollution impact. Biol Lett 8:218-221

Murray S, Wanless S, Harris M (2014) The Bass Rock-now the world's largest northern gannet colony. Br Birds 107: $769-770$ 
Murray S, Harris MP, Wanless S (2015a) The status of the gannet in Scotland in 2013-14. Scott Birds 35:3-18

Murray S, Morgan G, Harris MP (2015b) A count of northern gannets on Grassholm in 2015. Br Birds 108:691-692

Nelson B (2002) The Atlantic gannet. Fenix Books, Norfolk

Newton I (2008) The migration ecology of birds. Academic Press, London

Patrick SC, Bearhop S, Bodey TW, Grecian WJ, Hamer KC, Lee J, Votier SC (2015) Individual seabirds show consistent foraging strategies in response to predictable fisheries discards. J Avian Biol 46:431-440

Phillips RA, Silk JRD, Croxall JP, Afanasyev V, Briggs DR (2004) Accuracy of geolocation estimates for flying seabirds. Mar Ecol Prog Ser 266:265-272

Phillips RA, Bearhop S, McGill RAR, Dawson DA (2009) Stable isotopes reveal individual variation in migration strategies and habitat preferences in a suite of seabirds during the nonbreeding period. Oecologia 160:795-806

Phillips RA, Lewis S, González-Solís J, Daunt F (2017) Causes and consequences of individual variability and specialization in foraging and migration strategies of seabirds. Mar Ecol Prog Ser 578:117-150

Pistorius PA, Hindell MA, Tremblay Y, Rishworth GM (2015) Weathering a dynamic seascape: influences of wind and rain on a seabird's year-round activity budgets. PLOS ONE 10:e0142623

Pradel R (1993) Flexibility in survival analysis from recapture data: handling trap-dependence. In: Lebreton JD, North PM (eds) Marked individuals in the study of bird populations. Birkhäuser Verlag, Basel, p 29-37

R Core Team (2016) R: a language and environment for statistical computing. R Foundation for Statistical Computing, Vienna. www.r-project.org

Redman KK, Lewis S, Griffiths R, Wanless S, Hamer KC (2002) Sexing northern gannets from DNA, morphology and behavior. Waterbirds 25:230-234

Sherley RB, Ludynia K, Dyer BM, Lamont $\mathrm{T}$ and others (2017) Metapopulation tracking juvenile penguins reveals an ecosystem-wide ecological trap. Curr Biol 27: 563-568

Sherman K (1991) The large marine ecosystem concept: research and management strategy for living marine resources. Ecol Appl 1:349-360

Stauss C, Bearhop S, Bodey TW, Garthe S and others (2012) Sex-specific foraging behaviour in northern gannets Morus bassanus: incidence and implications. Mar Ecol Prog Ser 457:151-162

Votier SC, Bearhop S, Witt MJ, Inger R, Thompson D, Newton $J$ (2010) Individual responses of seabirds to commercial fisheries revealed using GPS tracking, stable iso-

Editorial responsibility: Rory Wilson,

Swansea, UK topes and vessel monitoring systems. J Appl Ecol 47: 487-497

Votier SC, Archibald K, Morgan G, Morgan L (2011a) The use of plastic debris as nesting material by a colonial seabird and associated entanglement mortality. Mar Pollut Bull 62:168-172

*Votier SC, Grecian WJ, Patrick S, Newton J (2011b) Intercolony movements, at-sea behaviour and foraging in an immature seabird: results from GPS-PPT tracking, radiotracking and stable isotope analysis. Mar Biol 158: 355-362

Votier SC, Bicknell A, Cox SL, Scales KL, Patrick SC (2013) A bird's eye view of discard reforms: bird-borne cameras reveal seabird/fishery interactions. PLOS ONE 8:e57376

* Votier SC, Fayet AL, Bearhop S, Bodey TW and others (2017) Effects of age and reproductive status on individual foraging site fidelity in a long-lived marine predator. Proc R Soc B 284:20171068

Wakefield ED, Phillips RA, Matthiopoulos J (2009) Quantifying habitat use and preferences of pelagic seabirds using individual movement data: a review. Mar Ecol Prog Ser 391:165-182

Wanless S (2002) Northern gannet (gannet) Morus bassanus. In: Wernham CV, Toms MP, Marchant JH, Clark JA, Siriwardena GM, Baillie SR (eds) The migration atlas: movements of the birds of Britain and Ireland. T \& AD Poyser, London, p 130-132

Wanless S, Frederiksen M, Harris MP, Freeman SN (2006) Survival of gannets Morus bassanus in Britain and Ireland, 1959-2002. Bird Study 53:79-85

Weimerskirch H, Jouventin P (1987) Population dynamics of the wandering albatross, Diomedea exulans, of the Crozet Islands: causes and consequences of the population decline. Oikos 49:315-322

Wernham CV, Toms M, Marchant J, Clark J, Siriwardena G, Baillie S (eds) (2002) The migration atlas: movements of the birds of Britain and Ireland. T \& AD Poyser, London

White GC, Burnham KP (1999) Program MARK: survival estimation from populations of marked animals. Bird Study 46:S120-S139

White GC, Burnham KP, Anderson DR (2001) Advanced features of program MARK. In: Field R, Warren RJ, Okarma $\mathrm{H}$, Sievert PR (eds) Wildlife, land, and people: priorities for the 21st century. Proc 2nd Int Wildl Manag Congr. The Wildlife Society, Bethesda, MD, p 368-377

Zeeberg J, Corten A, de Graaf E (2006) Bycatch and release of pelagic megafauna in industrial trawler fisheries off northwest Africa. Fish Res 78:186-195

Zeller D, Cashion T, Palomares M, Pauly D (2018) Global marine fisheries discards: a synthesis of reconstructed data. Fish Fish 19:30-39

Submitted: July 27, 2018; Accepted: May 6, 2019

Proofs received from author(s): July 4, 2019 